\title{
小児化膿性膝関節炎の小経験
}

\author{
田 畑 聖 吾* 西 里 徳 重* 清 水 寛 一* 安 楽 喜 久**
}

\section{Arthroscopic Treatment for Septic Arthritis of the Knee in Children}

\author{
Shogo Tahata*, Tokushige Nishizato*, Hirokazu Shimizu*, \\ and Yoshihisa Anraku**
}

【はじめに】小児化膿性関節炎は緊急性を要する病態であり，診断・治療の遅れは変形や成長障害を併 発し，機能障害を生じる恐れがある. 当院で治療を行つた小児の化膿性膝関節炎の 2 例について報告する. 【症例】 2 例ともに女児でそれぞれ 4 歳と 6 歳であつた. 1 例は上気道炎の先行感染を認めアトピー性皮 膚炎の既往があった。【方法】初診時に関節穿刺と血液検査を行い, 上記診断にて同日経静脈的に抗生剂 の投与を開始し，全身麻酔下に関節鏡視下デブリドマンを施行した。持続洗浄は行わなかつた．抗生剂は CRP が陰性化するまで使用し，投与期間はそれぞれ 14 日と 24 日であつた。起炎菌を証明できたのは 1 例で，黄色ブドウ球菌であった.【結果およびまとめ】 2 例ともに CRP 正常化と局所症状の消失が得ら れ，最終調査時に成長障害，機能障害を認めていない．早期の関節鏡視下デブリドマンと抗生剤投与によ り短期的に良好な結果を得ることができた.

We performed arthroscopic debridement on two knees of two children. The patients were taken to the operating room in emergency situations and underwent arthroscopic treatment. The treatment was determined by the macroscopic appearance of the joint pathology. We used Seara's classification to distinguish macroscopic stage of septic arthritis. These two patients presented early macroscopic stage ( I , II), therefore we only performed arthroscopic debridement, and continuous irrigation drainage was not required. The infection was cured in these two patients with no recurrence. They also did not have any dysfunction and growth impairment.

Key words : septic arthritis (化膿性関節炎), childen (小児), arthroscopic debridement（鏡視下デ ブリドマン)

\section{は じめ に}

小児化膿性膝関節炎は早急な診断，治療を要し，診 断・治療の遅れは関節破壊や成長軟骨障害を引き起こ し，短縮や変形などの障害を残す恐れがある．小览化 膿性膝関節炎に対して関節鏡下デブリドマンを行い良 好な結果を得た 2 例を経験したので報告する.

症例

【症例 1】 4 歳, 女览.

【現病歴】 1 週間前に感冒症状出現し, その後より左 膝痛出現した. 近医受診し特に異常を指摘されなかつ たが, 症状改善しないため当院小児科受診し, 精査加
療目的に当科紹介となる.

【既往症】アトピー性皮膚炎.

【初診時所見】左膝の発赤, 腫脹, 熱感, を認め血液 検査では白血球 $9000 / \mu \mathrm{l}, \mathrm{CRP} 5.1 \mathrm{mg} / \mathrm{dl}$ と炎症反 応を認めた。関節液を穿刺すると $10 \mathrm{ml}$ の混濁著明な 膿性の排液を認め, 生化学検査では白血球は 23700/ $\mathrm{mm}^{3}$ と著明に増加し, 血糖は $49 \mathrm{mg} / \mathrm{dl}$ と低下してい た. 単純レントゲンで関節内の軟部組織の腫大および 伸展制限を認め（図 1)，化膿性膝関節炎と診断し， 同日関節鏡視下デブリドマンを施行した.

【関節鏡所見】混濁した関節液が充満しており，増生 した滑膜組織には血餅が付着していた（図 2)。しか しながら, 滑膜の癒着はなく関節内の軟骨面の異常を

\footnotetext{
* 人吉総合病院整形外科 Department of Orthopaedics Surgery, Hitoyoshi General Hospital, Kumamoto, Japan

***済生会熊本病院整形外科 Department of Orthopaedics Surgery, Saiseikai Kumamoto Hospital, Kumamoto, Japan
} 


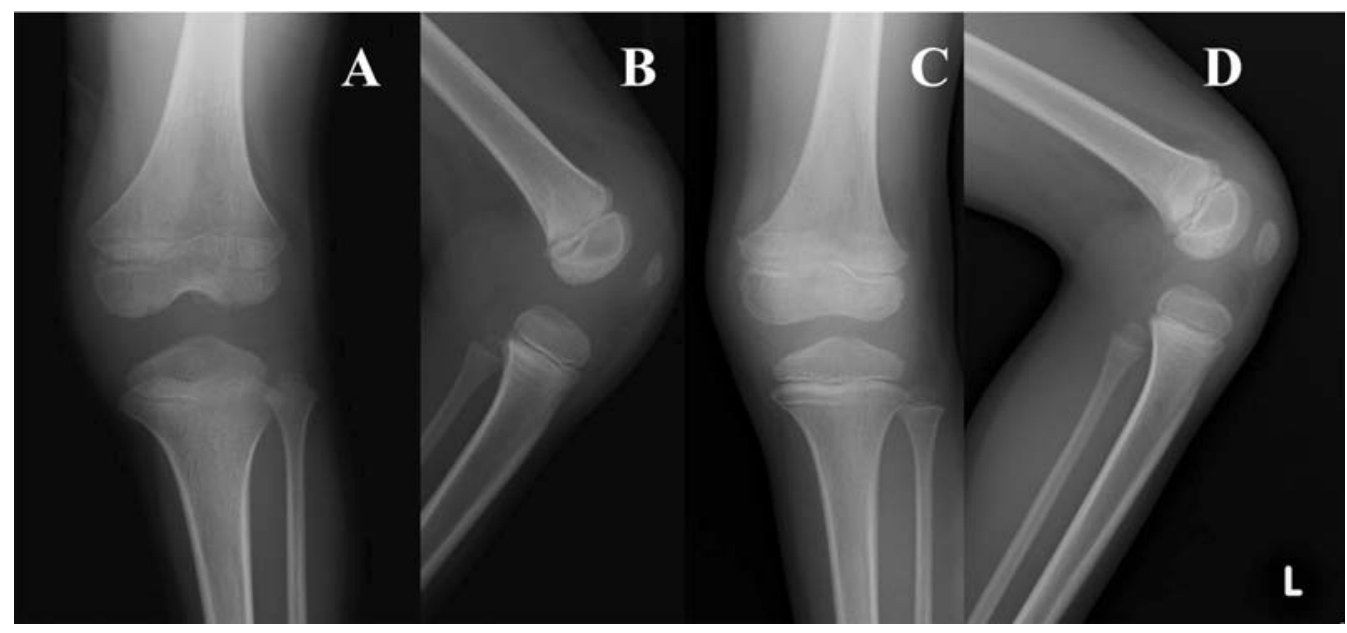

図 1 症例 1

初診時単純 $\mathrm{X}$ 線 $(\mathrm{A}, \mathrm{B})$, 最終追跡時単純 $\mathrm{X}$ 線 $(\mathrm{C}, \mathrm{D})$

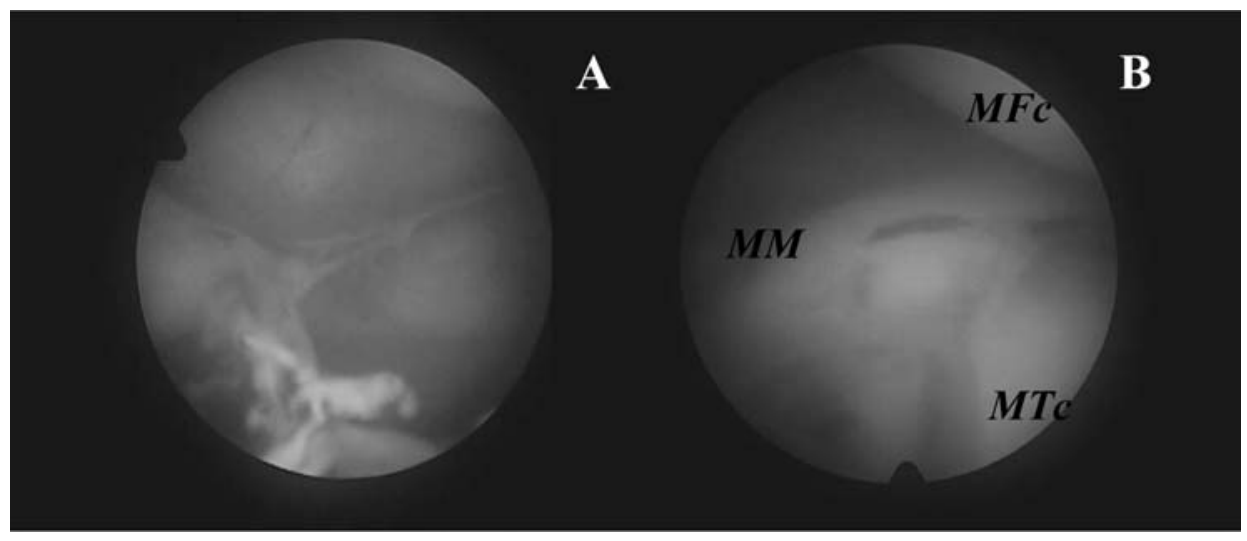

図 2 関節鏡所見（症例 1$)$

A. 膝蓋上囊 B. 内側関節裂隙

認めなかつた. 関節液培養検査の結果は黄色ブドウ球 菌であった．当日よりセファメジン (CEZ) の点滴投 与を行い, 起因菌の薬剂感受性判明後フルマリン (FMOX) に変更し術後 15 日目に炎症反応は軽快し た. 術後 1 年の最終追跡時に単純レントゲン上異常所 見はなく（図 1)，機能障害，成長障害を認めていな ().

【症例 2】6 歳女巟.

【現病歴】特に誘引なく右膝痛出現し, 近医より右膝 関節炎の診断で当科紹介となる.
【初診時所見】 $37.8^{\circ} \mathrm{C}$ の発熱と右膝の発赤, 腫脹, 熱感を認め, 血液検査では白血球 $15030 / \mu 1, \quad C R P$ $2.2 \mathrm{mg} / \mathrm{dl}$ と炎症反応を示した。関節穿刺で軽度混濁 した黄色の排液を認めた。初診時のレントゲン検査で は特に異常を認めず（図 3)，塗抹検査は陰性であっ たが，理学所見及び関節液の性状より化膿性膝関節炎 が疑われ同日関節鏡視下デブリドマンを施行した。

【関節鏡所見】滑膜の増生は軽度であったが，組織は 充血していた．軟骨面及びその他の関節内構成体には 異常を認めなかった。 当日よりセファメジン (CEZ) 


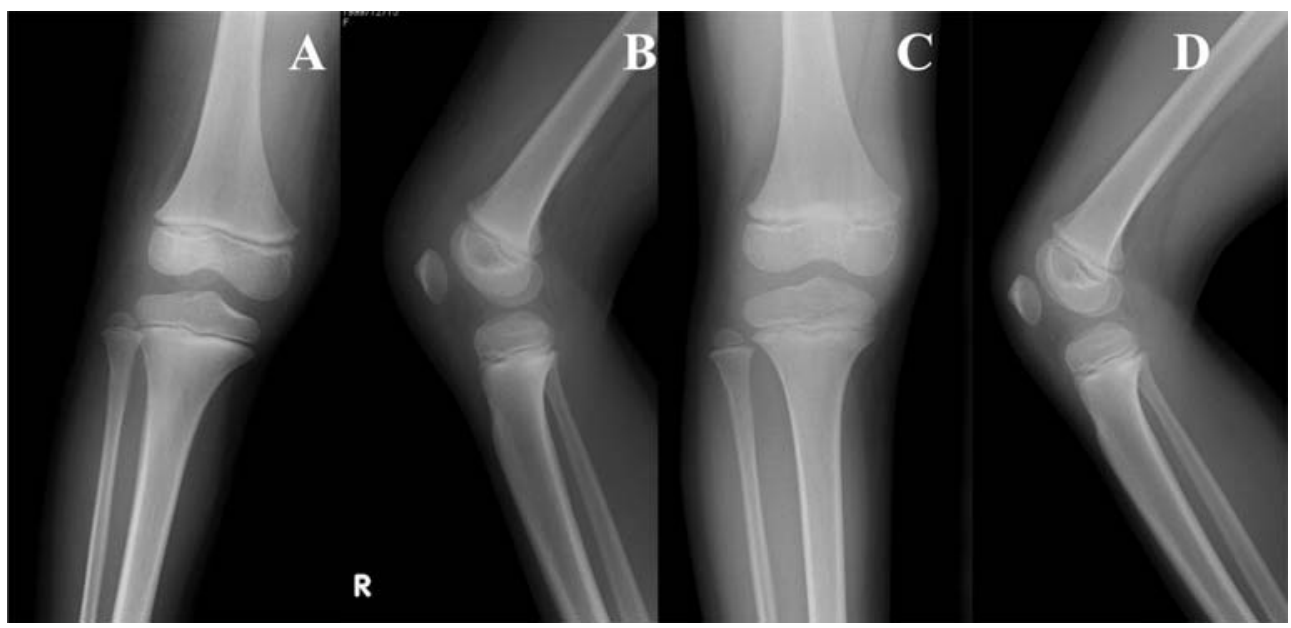

図 3 症例 2

初診時単純 $\mathrm{X}$ 線 $(\mathrm{A}, \mathrm{B})$, 最終追跡時単純 $\mathrm{X}$ 線 $(\mathrm{C}, \mathrm{D})$

の点滴投与を行い, 術後 14 日目に炎症反応は軽快し た. 術後 1 年の最終追跡時, 機能障害はなく, 単純 X 線検査上も成長障害は認めていない（図 3).

\section{考察}

化膿性膝関節炎では，発熱，膝周囲の発赤・腫脹・ 熱感を認め, 血液検查では白血球の増加， CRP 陽性, 血沈值妄進などの炎症反応を認める。また関節液検査 では白血球数の著明な増加とグルコース濃度の低下が 特徵で，塗抹鏡検や培養検查で診断を確定する。しか し細菌が同定できないケースも少なくない，Weston ら ${ }^{6}$ によると, 化膿性関節炎の起因菌としては黄色ブ ドウ球菌が最も多く, 連鎖球菌, 肺炎球菌がこれに続 く，起因菌が同定されるまでは，これらを念頭に抗生 剤を選択するが，本症例はブドウ球菌をターゲットに セフェム系抗生剂を選択した。しかし，近年メチシリ ン耐性球菌（MRSA）の占める割合が高くなってい ることも示されており2)，起因菌の薬剤耐性が判明す れば最も有効な薬剤に変更することが必要である.

化膿性膝関節炎の治療は, 局所の安静と抗生剂の投 与を基本とし, 開放運動療法 ${ }^{1}$, 切開排膿2), 持続洗浄 法2337) など種々の方法が行われているが，関節鏡視下 手術のみで良好な結果がえられたとする報告も散見さ れる(1)8. 当院では理学所見より化膿性膝関節炎が否定 できない場合，早期に抗生剂の投与を開始し関節鏡視
表 1 化膿性関節炎の関節鏡視下ステージ

\begin{tabular}{c|l}
\hline \hline Stage & \multicolumn{1}{|c}{ 所 見 } \\
\hline I & 関節液の混濁, 滑膜の充血 \\
II & 膿性関節液, 滑膜組織の肥厚・易出血性 \\
III & 絨毛性滑膜炎, 癒着 \\
IV & 軟骨の融解, 骨びらん \\
\hline
\end{tabular}

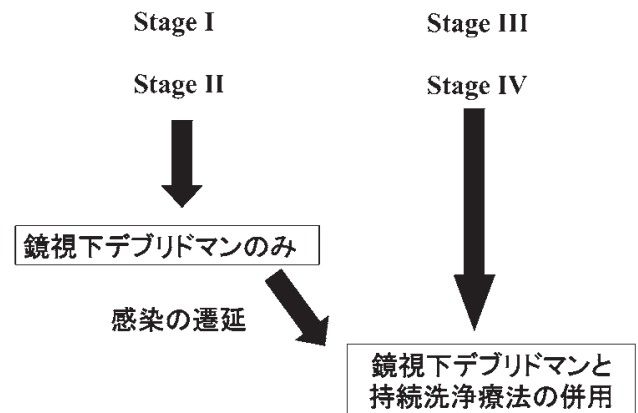

図 4 当科での治療指金

下デブリドマンを行い，Seara の分類（表 1）を参考 にその後の治療方針を決定している5 . Stage I , II の軽症例では関節鏡視下デブリドマンのみを行い, Stage III，IVの進行症例に対しては持続洗浄を併用す る（図 4)，今回の 2 症例はともに軽症例で，関節鏡 視下デブリドマンのみ施行した. 
関節鏡は低侵襲で関節内を十分に観察でき同時に洗 浄・病巣掻爬が出来る有用な方法であり, 経験した症 例では早期に炎症の沈静化が図れ，良好な結果につな がった.しかし, 術後症状の改善が得られず感染の遷 延化が疑われる場合には再度鏡視下デブリドマンと持 続洗浄を行う必要があると考える.

$$
\text { ま と め }
$$

(1)小児化膿性膝関節炎の 2 例を報告した.

(2)関節鏡視下デブリドマンは化膿性膝関節炎に対し 有効な治療法であった.

$$
\text { 参 考 文 献 }
$$

1）平野真子ら：化膿性肩関節炎における開放運動療法の
経験．整外と災外，52(1)：101-105，2003。

2）小林裕明ら：小児化膿性膝関節炎の小経験。日本骨 · 関節感染症研究会雑誌, $15: 51-54,2001$.

3）小林龍生：小览化膿性膝関節炎の診断と治療. Monthly Orthopaedics, 18(5) : 113-118, 2005.

4) 内藤温友ら：化膿性関節炎を疑い関節鏡視下デブリド マンを行った 18 例. 整外と災外, 53(1)：40-42, 2004.

5) Seara, J. L. V., et al.: Arthroscopic treatment of septic joint; prognostic factor. Arch. Orthop. Trauma Surg., 122 : 204-211, 2002.

6) Weston, V.C., et al.: Clinical features and outcome of septic arthritis in a single UK Health District 1982-1991. Ann. Rheum. Dis., 58 : 214-219, 1999.

7) 山本隆一郎ら：小児化膿性膝関節炎の小経験。中部整 災誌, $33: 715-716,2005$.

8）吉矢晋一ら：化膿性膝関節炎に対する関節鏡視下滑膜 切除術の治療成績. 膝, $22: 67-70,1996$. 